\title{
Effect of Nitrogen Levels and Seed Rate on Growth and Yield of Rye Grass (Lolium multiflorum) in Assam, India
}

\author{
Sarat Sekhar Bora ${ }^{1 *}$, Karuna K. Sharma ${ }^{1}$, Karishma Borah ${ }^{2}$ and Milon Jyoti Konwar ${ }^{1}$ \\ ${ }^{1}$ Department of Agronomy, ${ }^{2}$ Department of Horticulture, Assam Agricultural University, \\ Jorhat, Assam 785013, India \\ *Corresponding author
}

\section{A B S T R A C T}

Keywords

Nitrogen levels, seed rate, rye grass, green forage yield

Article Info

Accepted:

20 August 2019

Available Online:

10 September 2019
A field experiment was conducted at the Instructional-cum-Research (ICR) farm, Assam Agricultural University, Jorhat during 2016-2017. The experiment was laid out in split-plot design with thrice replication. The treatments consisted of three different seed rates in main plot viz., $10 \mathrm{~kg} / \mathrm{ha}, 15$ $\mathrm{kg} / \mathrm{ha}$ and $20 \mathrm{~kg} / \mathrm{ha}$ along with four nitrogen levels viz., $0 \mathrm{~kg} / \mathrm{ha}, 30 \mathrm{~kg} / \mathrm{ha}, 60$ $\mathrm{kg} / \mathrm{ha}$ and $90 \mathrm{~kg} / \mathrm{ha}$ in sub-plots. Results revealed that seed rates and nitrogen levels effects rye grass various growth and yield parameters. A seed rate of 20 $\mathrm{kg} / \mathrm{ha}$ was found to be statistically superior in regards to growth parameters in all the three cuts viz. 1st, 2nd and 3rd cut as compared to $15 \mathrm{~kg}$ and $10 \mathrm{~kg}$ seed rate/ha. The highest green forage yield (330.30 q/ha) was obtained with seed rate of $20 \mathrm{~kg} / \mathrm{ha}$ and was significantly superior to $15 \mathrm{~kg} / \mathrm{ha}$ and $10 \mathrm{~kg} / \mathrm{ha}$. The dry matter yield were also found to be significantly higher in seed rate of 20 $\mathrm{kg} / \mathrm{ha}(71.88 \mathrm{q} / \mathrm{ha})$. In case of nitrogen levels application of $90 \mathrm{~kg} \mathrm{~N} / \mathrm{ha}$ resulted in higher values in almost all the growth and yield parameters. The highest green forage yield (381.43 q/ha) was also obtained in $90 \mathrm{~kg} \mathrm{~N} / \mathrm{ha}$ and was significantly superior to all other lower doses of nitrogen $(60 \mathrm{~kg}$ and $30 \mathrm{~kg}$ N/ha).

\section{Introduction}

India is the largest producer as well as consumer of dairy products which mainly comes from the livestock. The livestock population is primarily dependent on crop residues. Feeding the animals with quality fodder is a major challenge for the farmers.
As a consequence the chronic shortage of feed and fodder resources indicate that most of the livestock are under fed. Such shortage on feed and fodder resources combined with to growing livestock population and less emphasis on forage cultivation by the livestock owners resulted in low productivity animals. Proper crop planning is a pre 
requisite for uninterrupted supply of nutritious green fodder for maintaining the higher productivity of dairy animals. Moreover, winter months are considered as the lean period for the fodder supply. So, growing winter forage is very important to cop up with fodder shortage during the lean period.

Rye grass (Lolium spp.) is a cool season forage to feed the ruminant animals. It is fast germinating, quick growing and requires low to medium fertilization. In Assam, presently the oat is the only cereal fodder with green fodder production from two numbers of cuts.. In view of this rye grass is a suitable option as rabi forage crops which has numbers of merits over oat in respect of yield, productivity and quality. On there is good correlation between seed rate, plant population and increasing levels of nitrogen in relation to herbage yield. In view of this fact there is need to generate more research information on two important component technologies viz. suitable seed rate and nitrogen levels as this is a new forage crops for Assam. So, the present study has been undertaken to find out the proper seed ratein combination with suitable level of nitrogen to see the growth as well as green forage yield of rye grass.

\section{Materials and Methods}

The experiment was laid out in split-plot design with thrice replication. The treatments consisted of three different seed rates in main plot viz., $10 \mathrm{~kg} / \mathrm{ha}, 15 \mathrm{~kg} / \mathrm{ha}$ and $20 \mathrm{~kg} / \mathrm{ha}$ along with four nitrogen levels viz., $0 \mathrm{~kg} / \mathrm{ha}$, $30 \mathrm{~kg} / \mathrm{ha}, 60 \mathrm{~kg} / \mathrm{ha}$ and $90 \mathrm{~kg} / \mathrm{ha}$ in sub-plots. Variety PRG-1 was used which is a promising rye grass variety developed by the Punjab Agricultural University. It is a multicut cereal fodder and gives about three to four cuttings in rabi season. It is highly nutritious, palatable and easily digestible fodder crop. It is quick growing variety and its first cutting is ready in about 55 days after sowing and subsequent cuttings can be taken after an interval of about
30-35 days. The variety was sown on $12^{\text {th }}$ November, 2016 and the fertilizers were applied one day ahead of sowing. Nitrogen was applied in 3 split doses i.e., $1 / 2$ of $\mathrm{N}$ is applied in final ploughing, $1 / 4$ at $1^{\text {st }}$ cut and remaining $1 / 4$ at $2^{\text {nd }}$ cut as per the treatment. All the phosphatic and potassic fertilizers were applied at the rate of $187 \mathrm{~kg} / \mathrm{ha}$ of SSP and 50 $\mathrm{kg} / \mathrm{ha}$ of MOP, respectively.

\section{Results and Discussion}

\section{Growth Parameters}

\section{Plant height}

Plant height of grasses plays a positive role in increasing forage productivity. It was revealed that the height of the plants differs significantly (Table 1). With the increasing levels of nitrogen plant height increased significantly. The highest plant height was recorded in rye grass grown with higher nitrogen levels as compared to lower levels. Plant height of rye grass gave positive response to the levels of nitrogen. The increase in plant height due to application of nitrogen might be because of stimulating affect of nitrogen on various physiological processes of plant. Sood (1981) reported that increase in nitrogen levels from $60-120 \mathrm{~kg}$ $\mathrm{N} /$ ha brought significant increase in plant height, green as well as dry fodder during all the 3 years of study. The findings of the present experiment also in conformity with Kunelius (2004). Seed rate also have a positive role in increasing the plant height. With the increasing of higher seed rate the plant height increases which may be due to the increasing population in the area.

\section{Tillers/m $\mathbf{m}^{2}$}

Significant difference in number of tillers $/ \mathrm{m}^{2}$ was found in case of nitrogen levels and was shown in Table 1. However, the highest 
number of tillers $/ \mathrm{m}^{2}$ was found at first and third cut and as compared to second cut. With the increased levels of nitrogen, tillers increased significantly. The number of tillers $/ \mathrm{m}^{2}$ tended to increase in the subsequent cuts might be due to the fact that cutting promotes the development of new shoots.

Application of higher doses of nitrogen increased the availability of nutrients in soil which enhanced the uptake of nutrients and reflected in terms of higher number of tillers $/ \mathrm{m}^{2}$ over 25 per cent < RDNF. Soni et al., (1991) revealed that number of tillers per tussock increased with increasing nitrogen rates up to $120 \mathrm{~kg} / \mathrm{ha}$. This was also in conformity with the findings of Dwivedi et al., (1991).

Seed rate also have a positive role in increasing the tillers $/ \mathrm{m}^{2}$. With the increasing of higher seed rate the tillers $/ \mathrm{m}^{2}$ increases which may be due to the increasing population in the area.

\section{Yield Parameters}

\section{Green forage yield (q/ha)}

Perusal of the data presented in Table 2 revealed that the annual grass viz. rye grass in all the three cuts differed significantly with each other due to application of different levels of nitrogen. Highest application of nitrogen was found to produce highest green forage in all the three cuts, respectively. It was revealed that with increasing levels of nitrogen, green forage yield increased significantly. Among the different levels of nitrogen, 50 per cent $>$ RDNF resulted in highest green forage yield under both the conditions. Application of higher nitrogen $(50 \%>$ RDNF) significantly increased the green forage yield over RDNF application. Linear increase in green forage production was noticed with every successive nitrogen level over its preceding level as adequate nitrogen supply improves the plant height and over all biomass of cereal and forage crops which directly influence the fodder production.

The perennial grasses respond well to the application of higher doses of nitrogen. Rai and Kanodia (1981) reported maximum yield of green fodder was recorded with the application of $120 \mathrm{~kg} \mathrm{~N} / \mathrm{ha}$. This was also in conformity with the findings of Sood (1981), Chonamki et al., (2003) and Kunelius (2004).

Seed rate also have a increases the green forage yield. With the increasing of higher seed rate the population of the grass increases which may resulted in increase of the green forage.

On the basis of the field studies of one year, it was observed that rye grass significantly responded to increased nitrogen levels and seed rate showing positive effect on all growth and yield parameters like plant height, tillers $/ \mathrm{m}^{2}$ and also yield of green forage.

Application of $20 \mathrm{~kg}$ /ha seed rate and $90 \mathrm{~kg}$ $\mathrm{N} / \mathrm{ha}$ has been found to be more productive and profitable in rye grass. Hence researchers need to do research in this field before drawing conclusion and put forward for recommendation to the farming community. 
Table.1 Effect of nitrogen levels and seed rate on plant height $(\mathrm{cm})$ and tillers $/ \mathrm{m}^{2}$ of rye grass

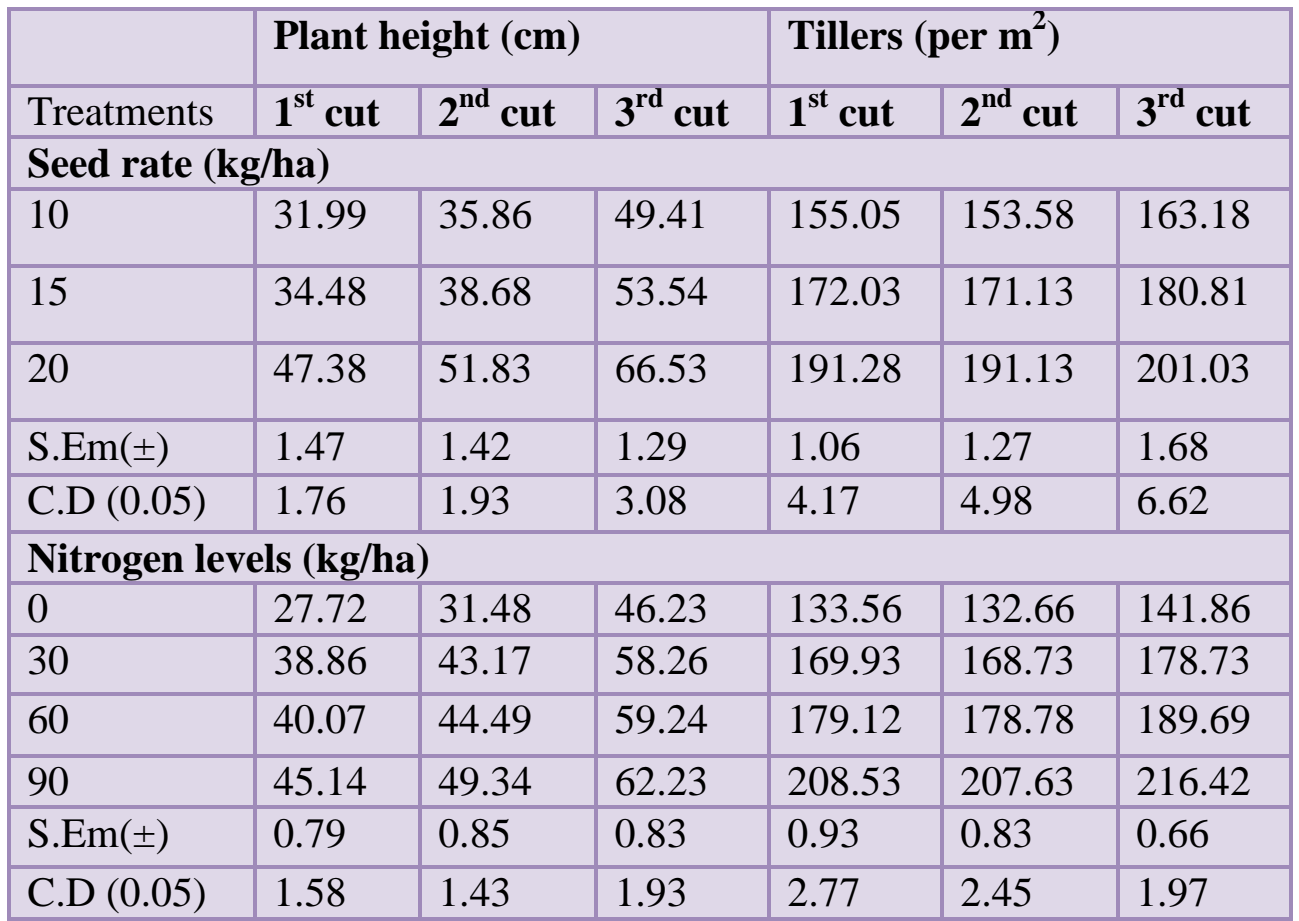

Table 2.Effect of nitrogen levels and seed rate on green forage yield (q/ha) of rye grass

\begin{tabular}{|l|l|l|l|l|}
\hline Treatments & $\mathbf{1}^{\text {st }}$ cut & $\mathbf{2}^{\text {nd }}$ cut & $\mathbf{3}^{\text {rd }}$ cut & Total \\
\hline Seed rate (kg/ha) \\
\hline 10 & 53.76 & 83.62 & 93.65 & 231.03 \\
\hline 15 & 69.03 & 99.33 & 108.85 & 277.21 \\
\hline 20 & 84.03 & 118.27 & 128.00 & 330.30 \\
\hline S.Em( \pm$)$ & 1.41 & 1.17 & 1.44 & 3.93 \\
\hline C.D $(0.05)$ & 5.52 & 4.59 & 5.64 & 15.45 \\
\hline Nitrogen levels (kg/ha) \\
\hline 0 & 30.56 & 60.94 & 70.56 & 162.06 \\
\hline 30 & 67.56 & 96.53 & 107.43 & 271.52 \\
\hline 60 & 75.46 & 108.79 & 118.79 & 303.03 \\
\hline 090 & 102.20 & 135.34 & 143.89 & 381.43 \\
\hline S.Em( \pm$)$ & 0.77 & 0.86 & 1.11 & 2.58 \\
\hline C.D $(0.05)$ & 2.27 & 2.56 & 3.31 & 7.66 \\
\hline
\end{tabular}




\section{References}

Chonamki, Kang Youngkel, Song Changkhel, KoDonghwan and Cho Yongll (2003). Effect of $\mathrm{N}$ application rates on growth characters and feed value in Jeju Italian millet.J. of Korean Soc. of Grassland Science 23(2): 71-76.

Dwivedi, G.K.; Kanodia, K.C. and Rai, P. (1991). Response of setaria varieties to fertilizer nitrogen for seed yield and its attributes.Indian J. Agric. Res. 25(2): 92-101.

Kunelius, H.T., K.B. McRae, G.H. Dürr and S.A.E. Fillmore. 2004. Management of
Italian and perennial ryegrasses for seed and forage production in crop rotations. J. Agron. Crop. Sci. 190: 130-137.

Sood, B.R. (1981). Effect of methods of introduction and fertilizer management on the production potential and quality of natural grassland of Kangra valley. Thesis submitted to Himachal Pradesh KVV, Palampur for Ph.D. degree.

Soni, K.C. and Singh, D. (1991). Effect of nitrogen on the quality and green fodder yield of hybrid napier. Research and Development Reporter 8(2): 144147.

\section{How to cite this article:}

Sarat Sekhar Bora, Karuna K. Sharma, Karishma Borah and Milon Jyoti Konwar 2019. Effect of Nitrogen Levels and Seed Rate on Growth and Yield of Rye Grass (Lolium multiflorum) in Assam, India. Int.J.Curr.Microbiol.App.Sci. 8(09): 2110-2114.

doi: https://doi.org/10.20546/ijcmas.2019.809.244 